\title{
Adoption and Utilization of Family Planning Services among Couples in Rural-Urban Communities in Oyo State, Nigeria
}

\author{
Stella Akinso ${ }^{1 *}$, Folajinmi Oluwasina ${ }^{2}$, Amitabye Luximon-Ramma ${ }^{3}$ Femi Tinuola $^{4}$ \\ ${ }^{1}$ School of Public Health, Texila American University, Guyana \\ ${ }^{2}$ Faculty of Medicine and Dentistry, Department of Psychiatry, University of Alberta, \\ Edmonton, Canada \\ ${ }^{3}$ School of Health Sciences, University of Technology, Mauritius \\ ${ }^{4}$ Department of Sociology, Federal University, Gusau, Zamfara State
}

\begin{abstract}
Modern contraceptive use among couples has been documented to be a highly effective means of improving maternal health by preventing unintended pregnancies and maternal morbidity. Nigeria has a high fertility rate and poor contraceptive usage, marred by social and economic dimensions with other cultural norms, including gender disparity. This paper presents the findings of a cross-sectional quantitative study exploring the adoption and utilization of family planning services among couples in rural-urban communities in Oyo State, Nigeria. Systematic sampling technique was used to select 570 women and men of reproductive age in Rural-urban communities of the Oyo state, using a 54 semistructured questionnaire which included questions on socio-demographic characteristics, perception, socio-cultural factors, adoption, and utilization of modern contraceptive services. Of the 570 respondents, the mean age of the respondents was $30.3 \pm 7.8$ years. Most (63.3\%) of respondents were females, while $36.7 \%$ were males. The most common family planning methods respondents and their spouses had heard injectable (21.2\%), the male condom (18.6\%), and implants (15.1\%), IUD (13.4\%), and pills (13.2\%). Spousal support is 0.438 times more likely to influence utilization of modern family planning method and was statistically significant ( $\beta=-0.826$, Odd Ratio [OR]=0.438, $p<0.05)$. Similarly, stigmatization is 1.298 times more likely to influence the level of utilization of modern family planning methods $(\beta=0.261$, Odd Ratio [OR] $=1.298, p<0.05)$. It is important for government and family planning programmers to focus on programs that address stigmatization and effective spousal communication for improved modern contraceptive uptake.
\end{abstract}

Keywords: Adoption, Family Planning, Rural, Utilization, Urban.

\section{Introduction}

Nigeria is one of Africa's most populous countries [1]. It has high fertility of over 5 children by an average woman, while the use of modern contraceptives is low despite high knowledge of contraceptives [2]. Uptake of contraceptives has been marred by social and economic dimensions with other cultural norms, including gender disparity. Furthermore, urban residents are more likely to stop having children than those in rural areas. Generally, an average
Nigerian woman has about one child more than they desired [2], which implies that the current TFR is 15 percent higher than it would be if all unwanted births were avoided [2]. Several studies have shown gaps in family planning awareness and utilization, mostly due to poor awareness, fear of side effects, and other social and economic factors. Again, the perception remains a major challenge to the adoption of modern family planning methods [3].

The low uptake of contraceptives in Nigeria is 
likely to expose women to unplanned pregnancies, inadequate child spacing, and increased risks associated with closely spaced pregnancies and childbirth [2]. Given the crisis, children in poorly spaced births are more prone to malnutrition, diseases, and higher chances of death compared to those that are well spaced. This problem is likely to continue if the root causes are not identified and addressed. Understanding the factors that influence access to contraceptive use is key to reducing the disparities in family planning uptake and unmet needs for family planning across settings, including rural and urban areas.

Family planning has been proven to save and enhance the lives of women, children, and families. However, sub-Saharan Africans living in rural areas tend to use fewer contraceptives and have more children than their urban counterparts. Moreover, there continue to be widened gaps between awareness and the use of modern contraceptives.

A significant consequence of unwanted pregnancies is unsafe abortion. It is estimated that 1.25 million induced abortions were carried out in Nigeria in 2012, comparable to 33 abortions per 1,000 women of childbearing age in 2015 [4]. Improving access to modern contraceptives prevents unwanted pregnancies, some of which lead to unsafe abortion- a major cause of maternal mortality in Nigeria.

In 2018, the Global Family Planning Report revealed that Nigeria had recorded over 1.3 million unwanted pregnancies [4]. Low uptake of contraceptive methods is one of the leading factors contributing to high rates of unwanted pregnancies in Nigeria. Despite the widespread knowledge of contraception in Nigeria, only an abysmal 17 percent of currently married women use a contraceptive method while 12 percent of currently married women report using a modern contraceptive method, and unmet needs for family planning among currently married women is $19 \%[2,5]$. There is a disparity among rural and urban dwellers while the unmet need for $\mathrm{FP}$ is $20 \%$ among urban, it is low in rural with a record of 19 percent $[2,6,7]$. This inequity is fueled by both a growing population and a shortage of family planning services, poor knowledge, and access to contraceptives. This affects the TFR, which tends to be higher among rural than urban communities.

Gender divide and poor male approval are important to modern contraceptive uptake. Many women are afraid and may not be able to start the conversation around family planning even when they desperately need to use modern methods for fear of being labeled as promiscuous. Unlike in developed countries where men play key roles in supporting their spouses to use contraceptive methods [3]. In a study, men's attitude was generally positive; however, only 51 percent of the men sampled in his research reported knowledge about Family Planning [8]. More males have been reported to disapprove of attending family planning clinics with their spouses; less than a quarter of men in Nigeria individually initiate discussions to address issues related to when to achieve pregnancy, avoid pregnancy or take up a contraceptive method [8, 9].

Oyo state is one of the 36 states of Nigeria, and it prides itself as a pacesetter state where most social and development programs started, including Family Planning programs. Over the past ten years, the State has enjoyed the support of many development partners that have implemented family planning programs; however, the use of modern contraceptives has remained poor, particularly so in rural settings. Oyo State has a total fertility rate of $4.5 \%$, with a contraceptive prevalence of 22.6 (any method) and $22.2 \%$ for modern contraceptives. This is a decline from $24.4 \%$ in 2013 to $22.2 \%$ in $2018 \%$ $[2,6,7]$. Apart from socio-cultural barriers, access to contraceptive methods is extremely poor, particularly among the rural populace. Modern FP services are mostly provided by public and private health facilities and, in some cases, mission health facilities, while some access FP services from patent medicine vendors, pharmacist traditional providers $[2,7]$. 
In Oyo state, the contraceptive use among currently married women is more than twothirds (89.3\%), [2] as women reported that they decided jointly with their partners to use family planning. In addition, among currently married women who are non-users, almost three-quarters of them (70.9\%) decided jointly with their partner not to use family planning [2]. Thus, the decision-making input of the male partners cannot be over-emphasized.

Despite huge investment in family planning by donors and development partners, modern contraceptive prevalence remains poor in Oyo state at just $22.6 \%$ compared to other South Western states of Nigeria [2]. Among women aged 15-49 who are not using contraception, the percentage of women who did not discuss family planning either with a fieldworker or at a health facility was very high $(78.7 \%)$, with only $5 \%$ of women being visited by a fieldworker who discussed family planning in Oyo State [2]. There is robust research on family planning utilization among women in low-income countries, also many DHS report disparity in the knowledge and perception of contraceptives among women in rural and urban communities; however, there are few comparative studies on family planning acceptance and utilization among spouses (Men and Women of reproductive age) in rural and urban settings in Nigeria. This study examined the adoption and utilization of family planning among couples in rural-urban communities in Oyo state, Southwest area of Nigeria.

\section{Methods}

\section{Description of the Study Area}

Oyo State is one of the 36 states of Nigeria; it was carved out of the old western state inn1996. It is bounded by Osun, on the East and Kwara state by the North, Ogun on the south, and Benin republic on the West. It is occupied mainly by the Yoruba people who also speak the Yoruba language and has a population of about 8 million people, its main occupation is farming. There are 33 Local Government Areas (LGAs) in the state,
11 are in the urban while 22 are in the rural areas [10].

The study was conducted in 4 LGAs, 2 urban and two rural, these are:

\section{Ibadan North-West Local Government Area}

Ibadan North-West is an urban LGA with headquarter located in Dugbe/Onireke, Ibadan. It was carved out of the defunct Ibadan Municipal Government (IMG) on August 27, 1991, during the regime of former military President, retired General Ibrahim Babaginda. Its landmass extends to about $244.55 \mathrm{~km} 2$. This feature makes it one of the largest LGAs in Oyo State. It is bounded by Ibadan Northwest and Ido LGA in the North, by Oluyole LGA in the South, by Ido Local Government in the West, and by Ibadan North and South East LGA in the East. It has a population figure of 283,098 according to the results of the 2006 census released by the National Population Commission. The LGA has a total estimated population of 250,543 , and the estimated population for people of the reproductive age is 55119 [10].

\section{Ibadan South-East Local Government Area}

Ibadan South-East is also an urban LGA in Oyo State, Nigeria. It was created on $27^{\text {th }}$ August 1991 by the Federal Government and was carved out of the defunct Ibadan Municipal Government. The LGA covers an area of about 80.537 hectares of land. According to the 2006 census, Ibadan South-East LGA has a population of 266,4572020 is 436,133 whilst the estimated population for people of reproductive age is 95949. The LGA has a total of 12 wards [10].

\section{Kajola Local Government Area}

The LGA located in the northern part of Oyo State covers an area of $609 \mathrm{~km}^{2}$, and it is bounded in the south by Ibarapa LGA and Ogun State, in the east by Iseyin LGA, in the west by Iwajowa LGA and Republic of Benin, and in the northwest by Itesiwaju LGA. The 2006 census puts the GA population figure as 200,528 whilst 
the project population for 2016 is 281,700 . The total estimated population is 329,497 , with reproductive age put at 72,489 , and comprises 11 wards $[10,11]$.

\section{Oyo West Local Government Area}

Oyo West LGA is in the central of Oyo State. It bounds Atiba by the north, bounds Afijio by the south, bounds Iseyin by the west, and Oyo
East LGA. It covers an area of $505 \mathrm{~km}^{2}$, and the headquarters of the LGA is Ojongbodu. Based on the 2006 census, the population census of the LGA is 136,457 , and the projected population for 2016 is 191,700 . The estimated population of the LGA for 2020 is 223,334 , while the estimated population for people of reproductive age is 49133. The LGAs have ten (10) wards [10].

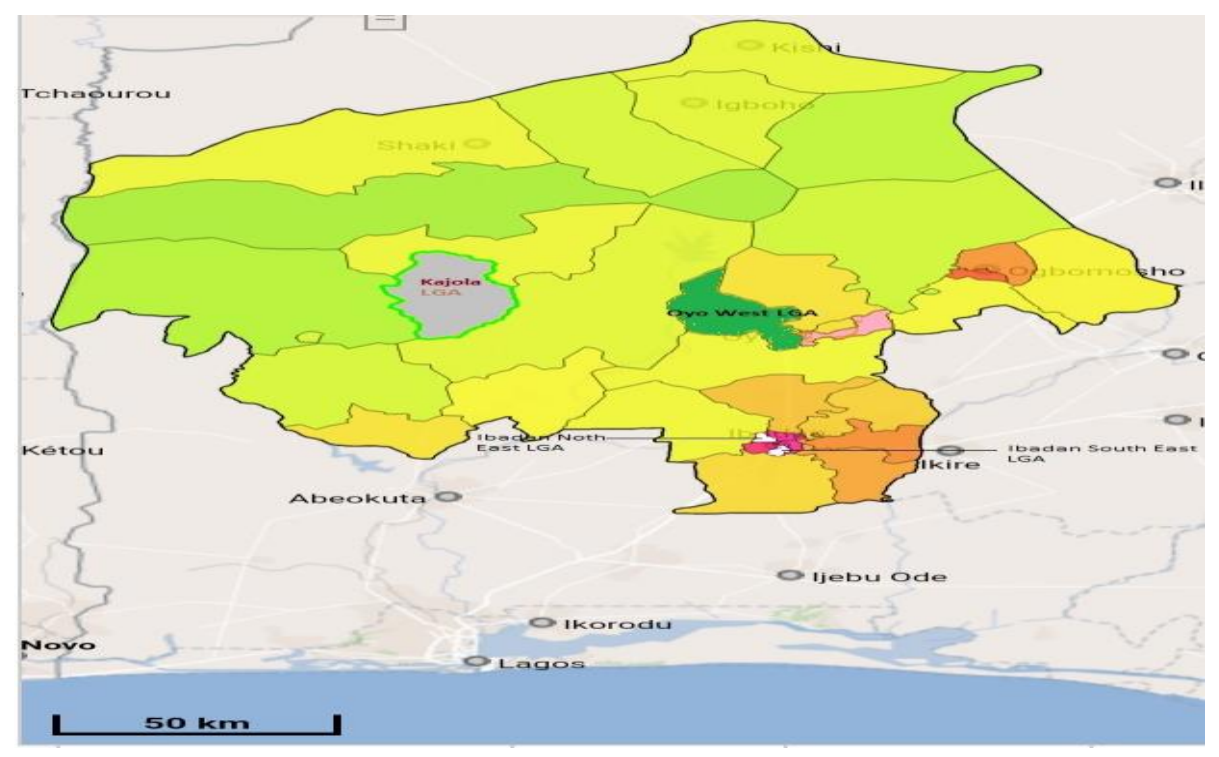

Figure 1. Study LGAs highlighted in Oyo state Map (City Map, 2020)

\section{Study Design}

This study is a descriptive cross-sectional study design. A descriptive cross-sectional study was used to assess related factors influencing the use of family planning among the study population. This type of study is usually used to describe the prevalence of variables of interest in a population.

\section{Study Population}

The study population consists of men and women of reproductive age between 18 to 49 years, including married adolescents and adults who have lived in the community for more than 2 years.

\section{Inclusion Criteria}

Men and women of reproductive age between 18 to 49 years who have lived in their communities for more than 2 years at the time of the study.

\section{Exclusion Criteria}

Men and women of reproductive age who are less than 18 yrs or older than 50 years, who have not lived in their communities for more than 2 years at the time of the study or persons who are not clinically stable or not within the enumerated area were not considered.

\section{Sample Size}

Sample size determination

$$
\mathrm{N}=\mathrm{DZ} 2 \mathrm{Pq}
$$

d2

Where:

$\mathrm{N}=$ sample size.

$\mathrm{D}=$ design effect $=2$.

$\mathrm{Z}=$ a constant at $95 \%$ precision $=1.96$.

$\mathrm{d}=$ desired precision at $5 \%$.

$\mathrm{q}=1-\mathrm{p}(1-0.219=0.781)$. 
$\mathrm{P}=$ Contraceptive Prevalence Rate $(\mathrm{CPR})$ in Oyo state $=22.6 \%$ (NDHS, 2018).

Therefore,

$$
\mathrm{N}=(2 \times 1.96 \times 1.96 \times 0.226 \times 0.774) /(0.05 \times
$$
$0.05)$.

$$
\begin{aligned}
& \mathrm{N} \sim 543 . \\
& 543+(5 / 10 \times 543)=570 . \\
& \mathrm{N}=570 .
\end{aligned}
$$

\section{Results}

Table 1 shows the socio-demographic profile of respondents in the study locations. Five hundred and seventy (570) participants across urban and rural communities (each accounted for $50 \%$ ) were sampled for the study. The commonly occurring age group of respondents within the reproductive age bracket was aged 3140 years $(34.6 \%)$ followed by the age group 26 30 years $(31.1 \%)$. The least age group was aged 41-49 years accounted for $16.7 \%$. A large proportion (63.3\%) of respondents who participated in this study were female compared to $36.7 \%$ male respondents. More than half (54.7\%) of respondents' religion was Islam, while below half $(44.0 \%)$ of the respondents were practicing Christian religion at the time of the study.

The majority (83.7\%) of the respondents were married compared to singles $13.7 \%$. The divorced/separated and widowed were very minute $(1.6 \%$ \& $1.1 \%)$ respectively. With regards to the primary occupation of the respondents, the majority (39.8\%) were traders, while one-fifth $(20.4 \%)$ were self-employed. The highest educational qualification of most of the respondents was a secondary school (60.4\%), followed by the tertiary level of education (18.4\%). The study location was predominantly dominated by Yoruba people, and a large proportion $(96.0 \%)$ of the respondents who participated in the study were Yoruba compare to Igbo (2.8\%) and Hausa (0.9\%).

Two in five $(38.9 \%)$ of respondents already had 3-4 children, while two-thirds (34.4\%) of the respondents already had 1-2 children. Approximately one in ten $(11.8 \%)$ respondents had above 5 children prior to the survey, while

\begin{tabular}{|c|c|c|}
\hline Characteristics & Frequency $(N=570)$ & Percentage (\%) \\
\hline \multicolumn{3}{|l|}{ Location } \\
\hline Urban & 285 & 50.0 \\
\hline Rural & 285 & 50.0 \\
\hline \multicolumn{3}{|l|}{ Age } \\
\hline $18-25$ & 101 & 17.7 \\
\hline $26-30$ & 177 & 31.1 \\
\hline $31-40$ & 197 & 34.6 \\
\hline $41-49$ & 95 & 16.7 \\
\hline \multicolumn{3}{|l|}{ Gender } \\
\hline Male & 209 & 36.7 \\
\hline Female & 361 & 63.3 \\
\hline \multicolumn{3}{|l|}{ Religion } \\
\hline Christianity & 251 & 44.0 \\
\hline Islam & 312 & 54.7 \\
\hline Traditional & 7 & 1.2 \\
\hline \multicolumn{3}{|l|}{ Marital Status } \\
\hline Single & 78 & 13.7 \\
\hline Married & 477 & 83.7 \\
\hline
\end{tabular}
$14.9 \%$ had no children as at the time of the survey.

Table 1. Socio-Demographic Characteristics of the Respondents 


\begin{tabular}{|l|l|l|}
\hline Divorced/Separated & 9 & 1.6 \\
\hline Widowed & \multicolumn{2}{l|}{} \\
\hline Occupation & \multicolumn{2}{l|}{} \\
\hline Unemployed & 6 & 1.1 \\
\hline Self employed & 116 & 20.4 \\
\hline Artisan & 99 & 17.4 \\
\hline Farming & 6 & 1.1 \\
\hline Govt. Worker & 38 & 6.7 \\
\hline Skilled job & 66 & 11.6 \\
\hline Trading & 227 & 39.8 \\
\hline Housewife & 7 & 1.2 \\
\hline Others & 5 & 0.9 \\
\hline Education & \multicolumn{2}{|l|}{} \\
\hline None & 6 & 1.1 \\
\hline informal & 5 & 0.9 \\
\hline Primary & 110 & 19.3 \\
\hline Secondary & 344 & 60.4 \\
\hline Tertiary & 105 & 18.4 \\
\hline Ethnicity & & \\
\hline Yoruba & 547 & 96.0 \\
\hline Igbo & 16 & 2.8 \\
\hline Hausa & 5 & 0.9 \\
\hline Other & 2 & 0.4 \\
\hline No of children & & 14.9 \\
\hline None & 85 & 34.4 \\
\hline 1-2 & 67 & 11.8 \\
\hline 3-4 & \multicolumn{2}{|l|}{} \\
\hline 5 \& above & \multicolumn{2}{|l|}{} \\
\hline
\end{tabular}

Table 2 shows the knowledge of respondents about the family planning method in the study locations. A large proportion (97.0\%) of respondents had heard of family planning in the past. The majority (33.3\%) of the respondents sourced information about family planning from health care providers, while $31.3 \%$ sourced their information from mass media - Radio, TV, or newspapers. Other respondents who sourced information about family planning from friends and relatives or social gatherings accounted for $13.8 \%$ and $10.6 \%$, respectively. The majority (81.2\%) of respondents' partners claimed they were already aware of family planning prior to the survey.
The most common family planning methods respondents and their spouses had heard injectable $(21.2 \%)$, the male condom $(18.6 \%)$, and implants (15.1\%), IUD (13.4\%), and pills (13.2\%). The least family planning methods respondents were aware of comprised of spermicides (1.5\%), female sterilization (1.5\%), and vasectomy $(1.3 \%)$. Approximately two in five $(41.9 \%)$ respondents got to know about family planning when they were still single, and over one-third (37.7\%) got to know about family planning after they have been married.

Prior to this survey, over two-thirds (69.3\%) of respondents had discussed family planning with their spouses. Two-third (66.6\%) of 
respondents discussed family planning with their spouse purposely to avoid unwanted pregnancy, while $16.2 \%$ used family planning to prevent abortion. Over half $(53.1 \%)$ of respondents who had not discussed family planning with their spouses claimed that it was unacceptable to discuss family planning with their spouses, while $38.9 \%$ claimed that they don't know how to discuss family planning with their spouses.
A large proportion of respondents had heard of family planning in the past, and the majority of the respondents sourced information about family planning from health care providers while others sourced their information from mass media. The most common family planning methods respondents and their spouses were aware of are injectable, male condoms, and implants.

Table 2. Respondents' Knowledge of Family Planning Method

\begin{tabular}{|c|c|c|}
\hline Respondents & Frequency $(\mathrm{N}=570)$ & Percentage $(\%)$ \\
\hline \multicolumn{3}{|c|}{ Ever heard of the family planning method } \\
\hline Yes & 553 & 97.0 \\
\hline No & 17 & 3.0 \\
\hline \multicolumn{3}{|c|}{ *Respondents' source of information about family planning } \\
\hline Health professional & 396 & 33.8 \\
\hline Mass media (TV/Radio, Newspaper) & 367 & 31.3 \\
\hline Internet & 56 & 4.8 \\
\hline Friends \& relatives & 162 & 13.8 \\
\hline Spouse/partner & 33 & 2.8 \\
\hline School & 34 & 2.9 \\
\hline Social gathering & 124 & 10.6 \\
\hline \multicolumn{3}{|c|}{ Respondents' partner aware of family planning } \\
\hline Yes & 453 & 81.2 \\
\hline No & 52 & 9.3 \\
\hline Don't know & 53 & 9.5 \\
\hline \multicolumn{3}{|c|}{ *Family planning method you or your partner is aware of } \\
\hline I can't remember & 29 & 1.9 \\
\hline Male condom & 292 & 18.6 \\
\hline Female condom & 121 & 7.7 \\
\hline withdrawal method & 48 & 3.1 \\
\hline Spermicides & 23 & 1.5 \\
\hline Pills & 206 & 13.2 \\
\hline Injectable & 332 & 21.2 \\
\hline Implants & 236 & 15.1 \\
\hline IUD & 209 & 13.4 \\
\hline Female sterilization & 23 & 1.5 \\
\hline Vasectomy & 21 & 1.3 \\
\hline Other methods & 24 & 1.5 \\
\hline \multicolumn{3}{|c|}{ When respondents get to know about the importance of family planning } \\
\hline When I was single & 239 & 41.9 \\
\hline After I got married & 215 & 37.7 \\
\hline After the birth of my last child & 96 & 16.8 \\
\hline Don't know the specific time & 9 & 1.6 \\
\hline
\end{tabular}




\begin{tabular}{|l|l|l|}
\hline At undergraduate days & 11 & 1.9 \\
\hline \multicolumn{2}{|l|}{ Respondents had ever discussed family planning with spouse/partner } \\
\hline Yes & 395 & 69.3 \\
\hline No & 175 & 30.7 \\
\hline Why respondents discuss FP with their spouse & \multicolumn{2}{l|}{} \\
\hline To avoid unwanted pregnancy & 263 & 66.6 \\
\hline To prevent abortion & 64 & 16.2 \\
\hline To ask for my husband permission to use FP & 19 & 4.8 \\
\hline Health reason & 9 & 2.3 \\
\hline To enable me to focus on my trade/job/career & 40 & 10.1 \\
\hline Why respondents haven't discussed FP with your spouse & \\
\hline I don't know how to discuss it with him/her & 68 & 38.9 \\
\hline Afraid of being stigmatized & 5 & 2.9 \\
\hline I am scared to discuss it with him/him & 7 & 4.0 \\
\hline It is unacceptable to discuss it with him/her & 93 & 53.1 \\
\hline Other reasons & 2 & 1.1 \\
\hline
\end{tabular}

*Multiple responses

Table 3 shows the utilization of family planning methods by respondents who participated in the study. As at the time of the survey, over half $(54.9 \%)$ of the respondents were currently using one or more methods of family planning in the study locations. The majority of respondents adopted the injectable method of family planning (28.4\%), followed by male condoms $(23.5 \%)$. The least methods used were over half female sterilization and vasectomy $(0.3 \%)$ each, $0.5 \%$ for spermicides, while the withdrawer method accounted for $2.2 \%$.

Almost half (48.8\%) adopted the family planning method to prevent unwanted pregnancy, while $34.3 \%$ used family planning to prevent sexually transmitted diseases. Approximately $70.0 \%$ of respondents agreed to the decision of their partner to use the modern family planning method.

Almost half (48.8\%) of respondents' choice of family planning method in both areas was basically to prevent unwanted pregnancies, followed by $34.3 \%$ of them who chose family planning to prevent sexually transmitted diseases.
A large proportion $(86.0 \%)$ of respondents would recommend modern family planning to friends or relatives.

Respondents who were not interested in the use of the family planning method as at the time of the survey opined that they want more children $(28.8 \%$ ), while $23.0 \%$ were fearful of the side effect and $17.8 \%$ were of the view that family planning interferes with sexual pleasures.

More respondents in urban areas were currently using family planning methods than respondents in rural areas $(61.8 \%$ vs. $38.2 \%)-$ table 4. Although there were more respondents in an urban area who used the family planning method than in rural areas of the study locations, respondents' utilization by duration - over 3 years usage in rural area was more than those in an urban area (55.5\% vs. $50.6 \%)$ respectively table 5 .

Two-third (66.7\%) of respondents used male condoms in urban areas compared to one-third $(33.3 \%)$ respondents in rural areas. Almost three-quarters $(73.7 \%)$ of respondents in urban areas used female condoms than slightly over one-quarter $(26.3 \%)$ in rural areas. A large proportion $(88.9 \%)$ in urban areas used pills than 
in rural areas (11.1\%), while implants were more used in rural areas $(73.6 \%)$ than in urban areas (26.4\%). There was no record of the utilization of sterilization methods in rural areas $(0.0 \%)$, unlike urban areas where (100\%) use a broad range of family planning such as spermicides, female sterilization, and vasectomy, respectively.

Table 3. Respondents' Utilization of Family Planning Method

\begin{tabular}{|c|c|c|}
\hline Respondents & Frequency $(\mathrm{N}=570)$ & Percentage $(\%)$ \\
\hline \multicolumn{3}{|c|}{ Respondents currently using family planning method } \\
\hline Yes & 313 & 54.9 \\
\hline No & 257 & 45.1 \\
\hline \multicolumn{3}{|c|}{ *Method of family planning respondents was using } \\
\hline Male condom & 87 & 23.5 \\
\hline Female condom & 38 & 10.3 \\
\hline Withdrawal method & 8 & 2.2 \\
\hline Spermicides & 2 & 0.5 \\
\hline Pills & 45 & 12.2 \\
\hline Injectable & 105 & 28.4 \\
\hline Implants & 53 & 14.3 \\
\hline IUD & 30 & 8.1 \\
\hline Female Sterilization & 1 & 0.3 \\
\hline Vasectomy & 1 & 0.3 \\
\hline \multicolumn{3}{|c|}{ Reasons for the respondents' choice of family planning methods } \\
\hline To prevent unwanted pregnancy & 240 & 48.8 \\
\hline To prevent sexually transmitted diseases & 169 & 34.3 \\
\hline It is available to use & 33 & 6.7 \\
\hline I have a better understanding of the cost & 23 & 4.7 \\
\hline Not costly & 27 & 5.5 \\
\hline \multicolumn{3}{|c|}{ Respondent's spouse/partner currently using any modern family planning method } \\
\hline Yes & 216 & 37.9 \\
\hline No & 354 & 62.1 \\
\hline \multicolumn{3}{|c|}{ Respondents agree to the decision of their partner to use the modern family planning method } \\
\hline Yes & 395 & 69.3 \\
\hline No & 175 & 30.7 \\
\hline \multicolumn{3}{|c|}{ Respondents would recommend modern family planning method to someone else } \\
\hline Yes & 490 & 86.0 \\
\hline No & 80 & 14.0 \\
\hline \multicolumn{3}{|c|}{ *Reasons respondents who were not interested in family planning method gave } \\
\hline Fear of side Effect & 71 & 23.0 \\
\hline Spousal disapproval & 42 & 13.6 \\
\hline Lack of awareness & 25 & 8.1 \\
\hline Cost & 3 & 1.0 \\
\hline Distance to the health facility & 1 & 0.3 \\
\hline Interferes with sexual pleasures & 55 & 17.8 \\
\hline Against religion & 22 & 7.1 \\
\hline Provider's attitude & 1 & 0.3 \\
\hline
\end{tabular}




\begin{tabular}{|l|l|l|}
\hline Wants more children & 89 & 28.8 \\
\hline *Reasons for Family planning rejection & \multicolumn{2}{|l|}{} \\
\hline Fear of side effect & 263 & 66.6 \\
\hline Spousal disapproval & 64 & 16.2 \\
\hline Cost & 19 & 4.8 \\
\hline Interferes with sexual pleasures & 9 & 2.3 \\
\hline Against religion & 40 & 10.1 \\
\hline
\end{tabular}

*Multiple responses

Table 4. Respondents' Utilization of Family Planning Method by Location

\begin{tabular}{|l|l|l|l|l|l|}
\hline \multirow{2}{*}{$\begin{array}{l}\text { Respondents currently using } \\
\text { the family planning method }\end{array}$} & Yes & No & $\boldsymbol{\chi}^{\mathbf{2}}$ & df & p-value \\
\cline { 2 - 4 } Urban & $\mathbf{n}(\boldsymbol{\%})$ & $\mathbf{n}(\boldsymbol{\%})$ & & & \\
\hline Rural & $176(61.8)$ & $109(38.2)$ & \multirow{2}{*}{10.78} & 1 & $0.001^{*}$ \\
\hline Total & $137(48.1)$ & $148(51.9)$ & & & \\
\hline
\end{tabular}

$* \mathrm{p}<0.05$

Table 5. Respondents' Utilization of Family Planning for the First Time by Duration

\begin{tabular}{|l|l|l|l|l|l|l|l|}
\hline \multirow{2}{*}{$\begin{array}{l}\text { How long did it take } \\
\text { respondents to start using } \\
\text { family planning method(s) }\end{array}$} & $\mathbf{6}$ months & About 1 year & $\mathbf{1 - 2}$ years & Over 3 years & $\boldsymbol{\chi}^{\mathbf{2}}$ & df & p-value \\
\cline { 2 - 6 } & $\mathbf{n}(\boldsymbol{\%})$ & $\mathbf{n}(\boldsymbol{\%})$ & $\mathbf{n}(\boldsymbol{\%})$ & & & \\
\hline Urban & $26(14.8)$. & $28(15.9)$ & $33(18.8)$ & $89(50.6)$ & 8.64 & 3 & $0.034^{*}$ \\
\hline Rural & $8(5.8)$ & $17(12.4)$ & $36(26.3)$ & $76(55.5)$ & & & \\
\hline
\end{tabular}

$* \mathrm{p}<0.05$

Logistic regression was used to test associations between various factors that influence the usage of modern contraception in the study locations. The multivariate logistic regression analysis was used to test the degree of associations between independent and dependent variables assessed using odds ratios. The overall model in table 6 shows that the factors identified were good predictors of the

dependent variable - adoption and utilization of family planning in the study location $(\beta=$ $-0.197, d f=1, p<0.05)$. The model was based on a dichotomous response variable - nonuse (0) and use (1) and /or categorical explanatory variable(s), which are various factors influencing the use of the modern family planning method.

Table 6. Model

\begin{tabular}{|l|l|l|l|l|l|l|}
\hline & $\begin{array}{l}\text { Beta } \\
\text { Coefficient }\end{array}$ & $\begin{array}{l}\text { Standard } \\
\text { Error }\end{array}$ & $\begin{array}{l}\text { Wald } \\
\text { Statistics }\end{array}$ & $\begin{array}{l}\text { Degree of } \\
\text { Freedom }\end{array}$ & P-value & $\begin{array}{l}\text { Odds Ratio } \\
\text { (OR) }\end{array}$ \\
\hline Constant & -0.197 & 0.084 & 5.484 & 1 & 0.019 & 0.821 \\
\hline
\end{tabular}

$* \mathrm{P}<0.05$

Factor's analysis was used for dimension reductions of all the influencing factors through principal component analysis. Four influencing factors were identified by principal component, which was used to determine principal component factors among the whole influencing factors of contraceptive use. The principal component identified factors, such as my husband, wife, or partner supports the use of modern contraceptives, family planning is 
foreign to our culture, stigmatization by people for using family planning, unmarried adolescents and youths should not use contraceptives.

Considering the factors influencing the utilization of the family planning method in the study locations, the logistics regression model shows that there was a significant association between spousal or partner support and the utilization of modern family planning methods in the locations observed for the study. Thus, spousal support is 0.438 times more likely to influence utilization of modern family planning method and was statistically significant $(\beta=$ -0.826 , Odd Ratio $[O R]=0.438, p<0.05)$.
There was a significant relationship between stigmatization for using family planning, and the level of utilization of modern family planning method in the locations observed for the study stigmatization is 1.298 times more likely to influence the level of utilization of modern family planning method $(\beta=$ 0.261$, Odd Ratio $[O R]=1.298, p<0.05)$.

However, spousal or partner support in using modern family planning and stigmatization become strong factors that influence the level of utilization of family planning methods in the study locations.

Table 7. Logistics Regression Model of Factors Influencing the Usage of Modern Contraception.

\begin{tabular}{|c|c|c|c|c|c|c|c|c|}
\hline \multirow{2}{*}{$\begin{array}{l}\text { Dependent variable: } \\
\text { Currently using } \\
\text { modern FP }\end{array}$} & \multirow[t]{2}{*}{$\begin{array}{l}\text { Beta } \\
\text { Coefficient }\end{array}$} & \multirow[t]{2}{*}{$\begin{array}{l}\text { Standard } \\
\text { Error }\end{array}$} & \multirow[t]{2}{*}{$\begin{array}{l}\text { Wald } \\
\text { Statistics }\end{array}$} & \multirow[t]{2}{*}{$\begin{array}{l}\text { Degree of } \\
\text { Freedom }\end{array}$} & \multirow[t]{2}{*}{ P-value } & \multirow{2}{*}{$\begin{array}{l}\text { Odds } \\
\text { Ratio } \\
(\text { OR }) \\
\end{array}$} & \multicolumn{2}{|c|}{$\begin{array}{l}\text { 95\% C.I. for } \\
\text { Odds Ratio }\end{array}$} \\
\hline & & & & & & & Lower & Upper \\
\hline Constant & 1.956 & 0.561 & 12.172 & 1 & 0.000 & 7.069 & & \\
\hline $\begin{array}{l}\text { My partner supports } \\
\text { the use of modern FP }\end{array}$ & -0.826 & 0.095 & 76.129 & 1 & $0.000 *$ & 0.438 & 0.364 & 0.527 \\
\hline $\begin{array}{l}\text { Family planning is } \\
\text { foreign to our culture }\end{array}$ & -0.022 & 0.091 & 0.060 & 1 & 0.807 & 0.978 & 0.818 & 1.170 \\
\hline $\begin{array}{l}\text { People will } \\
\text { stigmatize me for } \\
\text { using FP }\end{array}$ & 0.261 & 0.123 & 4.481 & 1 & $0.034 *$ & 1.298 & 1.019 & 1.652 \\
\hline $\begin{array}{l}\text { Unmarried } \\
\text { adolescent/ youth } \\
\text { should not use FP }\end{array}$ & 0.059 & 0.079 & 0.548 & 1 & 0.459 & 1.060 & 0.908 & 1.238 \\
\hline
\end{tabular}

$* \mathrm{P}<0.05$

Considering the socio-demographic factors influencing the utilization of the family planning method in the study locations, the logistics regression model shows that there was a significant association between the number of children respondents had and the utilization of the modern family planning method in the locations observed for the study. Thus, the number of children of respondents is 0.706 times more likely to utilization and usage of modern family planning method and was statistically significant $\quad(\beta=-0.349$, Odd Ratio $[O R]=$ $0.706, p<0.05)$.

However, the number of children of respondents becomes strong influencing factors that influence the level of utilization of family planning methods in the study locations. Other socio-demographic factors such as age, gender, marital status, religion, occupation, level of education, and ethnicity of respondents were not significant factors that influence the level of utilization of family planning in Nigeria. 
Table 8. Logistics Regression Model of Socio-demographic Factors Influencing the Usage of Modern

Contraception

\begin{tabular}{|c|c|c|c|c|c|c|c|c|}
\hline \multirow{2}{*}{$\begin{array}{l}\text { Dependent } \\
\text { variable: Currently } \\
\text { using modern FP }\end{array}$} & \multirow[t]{2}{*}{$\begin{array}{l}\text { Beta } \\
\text { Coefficient }\end{array}$} & \multirow[t]{2}{*}{$\begin{array}{l}\text { Standard } \\
\text { Error }\end{array}$} & \multirow[t]{2}{*}{$\begin{array}{l}\text { Wald } \\
\text { Statistics }\end{array}$} & \multirow[t]{2}{*}{$\begin{array}{l}\text { Degree of } \\
\text { Freedom }\end{array}$} & \multirow[t]{2}{*}{ P-value } & \multirow{2}{*}{$\begin{array}{l}\text { Odds } \\
\text { Ratio } \\
\text { (OR) } \\
\end{array}$} & \multicolumn{2}{|c|}{$\begin{array}{l}\text { 95\% C.I. for } \\
\text { Odds Ratio }\end{array}$} \\
\hline & & & & & & & Lower & Upper \\
\hline Constant & 1.108 & 0.825 & 1.805 & 1 & 0.179 & 3.029 & & \\
\hline Gender & -0.002 & 0.195 & 0.000 & 1 & 0.992 & 0.998 & 0.681 & 1.463 \\
\hline Age & -0.019 & 0.118 & 0.026 & 1 & 0.872 & 0.981 & 0.779 & 1.237 \\
\hline Religion & 0.075 & 0.169 & 0.198 & 1 & 0.656 & 1.078 & 0.774 & 1.500 \\
\hline Marital status & -0.111 & 0.200 & 0.305 & 1 & 0.581 & 0.895 & 0.605 & 1.326 \\
\hline Occupation & -0.076 & 0.043 & 3.142 & 1 & 0.076 & 0.927 & 0.852 & 1.008 \\
\hline Education & -0.115 & 0.126 & 0.838 & 1 & 0.360 & 0.891 & 0.697 & 1.140 \\
\hline Ethnicity & 0.500 & 0.309 & 2.619 & 1 & 0.106 & 1.649 & 0.900 & 3.021 \\
\hline Number of children & -0.349 & 0.142 & 6.024 & 1 & 0.014 & 0.706 & 0.534 & 0.932 \\
\hline
\end{tabular}

$* \mathrm{P}<0.05$

\section{Discussion and Conclusion}

Considering the factors influencing the utilization of the family planning method in the study locations, the logistics regression model shows that there was a significant association between spousal or partner support and the utilization of modern family planning methods in the locations observed for the study. Thus, spousal support is 0.438 times more likely than the utilization of the modern family planning method and was statistically significant $(\beta=-$ 0.826, Odd Ratio [OR] $=0.438, \mathrm{p}<0.05$ ).

Many studies corroborated the findings of this study on spousal support as important to family planning uptake. For instance, in a study [12], the researchers observed that majority of women in the study (50.3\% and $33.3 \%$, respectively) gave fear of troublesome side effects and husband's objections as reasons for not using family planning. Similar studies conducted among rural community dwellers in Cross River State in Nigeria where the question on "who makes the decision regarding family planning use" spousal support was the strongest predictor of birth control use $(\mathrm{OR}=0.567 ; 95 \% \mathrm{CI}=$ 0.391-0.821) suggesting that adoption of birth control is more likely when couples make a joint decision [13]. In other studies, joint household decision-making was also seen as a significant contributor to modern contraceptive use $[14,15$, $16,17,18]$.

Also, other studies found perception by male partners that health decisions should be made jointly was positively related to the use of modern contraceptive methods; the studies then concluded that communication between couples was important for partner's approval of contraceptive use. [14, 16, 17, 19, 20, 21].

Again, stigmatization was significant for not using family planning and level of utilization of modern family planning method in the locations; stigmatization is 1.298 times more likely to influence the level of utilization of modern family planning method $(\beta=$ 0.261$, Odd Ratio $[O R]=1.298, p<0.05)$.

This observation validates several other studies which observed stigmatization as a major barrier to the use of contraceptives. In a study [22] among young women in Ethiopia, the study observed that 30 percent of the respondent agreed to anticipated stigmatization as a barrier to using family planning (unmet needs). Stigma was also mentioned as barriers to accessing family planning in other studies conducted in Nigeria [8, 9, 13].

In conclusion, the majority of the respondents are knowledgeable about family planning; however, usage is still low, and therefore programs that enhance increase uptake of Family 
Planning services are highly recommended. Also, authorities at all levels should take into consideration the major barriers to Family planning service utilization and establish a sustainable system at both the state national level to improve the adoption and utilization of family planning services. A well-designed program that addresses stigmatization and spousal communication is imperative to effective family planning program implementation.

\section{Citations}

Stella Akinso et al., 2021: Rural-Urban disparity in the Adoption and Utilization of

\section{References}

[1] OECD (2012) NIGERIA-OVERVIEW- West Africa

Gateway

https://www.oecd.org/swac/publications/Nigeria_eversion_en_light.pdf.

[2] National Population Commission. [Nigeria] and ICF. (2019). Nigeria Demographic and Health Survey 2018. Abuja, Nigeria, and Rockville, Maryland, USA: NPC and ICF.

[3] Apanga, P. A., \& Adam, M. A. (2015). Factors influencing the uptake of family planning services in the Talensi District, Ghana. Pan African Medical Journal, 20(1).

[4] Guttmacher Institute Fact Sheet. (2015) Abortion in Nigeria.

[5] WHO. (2018). Family Planning/contraception fact sheet. Retrieved Feb.26, 2019, from: https://www.who.int/news-room/factsheets/detail/family-planning-contraception.

[6] Macro, I. C. F., \& National Population Commission. (2009). Nigeria demographic and health survey 2008. Abuja, Nigeria: National Population Commission and ICF Macro.

[7] National Bureau of Statistics (Nigeria). (2012). Annual Abstract of Statistics, 2012. National Bureau of Statistics Federal Republic of Nigeria [Online]. [8] Adeyemi A., Olugbenga-Bello A.I., Adeoye O., Salawu M., Aderinoye A., Agbaje M. (2016) Contraceptive Prevalence and determinants among women of reproductive age group in Ogbomoso, Oyo family planning services among couples in rural-urban communities in Oyo State, Nigeria (Under review).

\section{Acknowledgments}

I acknowledge the 570 (respondents) who participated in this study for their time and patience.

\section{Conflicts of Interest}

The authors declare no conflicts of interest.

State, Nigeria. Open Access J Contracept. 2016; 7:33-41 https://doi.org/10.2147/OAJC.S94826.

[9] Akokuwebe, M.E. and Ojo, O. A., (2016). Factors Influencing Acceptability of Family Planning among Women in Rural Communities in Ife Central Local Government Area, Osun State, Nigeria. Ibadan Journal of the Social Sciences, 14 (2),250-261. [10] Thomas, O. (2020). City Population - statistics, maps \& charts. Retrieved 09 25, 2020, from Oyo State in Nigeria: https://www.citypopulation.de/php/nigeriaadmin.php?adm1id=NGA031.

[11] Manpower Nigeria. (2020). Kajola local government area (L/G.A): Oyo state. Retrieved September 26, 2020 from Manpower Nigeria: https://www.manpower.com.ng/places/lga/687/kajol a.

[12] Esike C.O.U., Anozie O.B., Ani M., Ekwedigwe K., Onyebuchi A.K., Ezeonu P.O., et al. (2017) Barriers to family planning acceptance in Abakaliki, Nigeria. Tropical Journal of Obstetrics \& Gynaecology, 34:212-7.

[13]Etokidem, A. J., Ndifon, W., Etowa, J., \& Asuquo, E. F. (2017). Family planning practices of rural community dwellers in cross river state, Nigeria. Nigerian Journal of clinical practice, 20(6), 707-715. https://www.guttmacher.org/fact-sheet/abortionnigeria.

[14] Islam, A. Z. (2018). Factors affecting modern contraceptive use among fecund young women in 
Bangladesh: does couples' joint participation in household decision-making matter? Reproductive health, 15(1), 1-9.

[15]Donta B., Nair S., Saggurti N., Ghule M., Battala M., Dasgupta A., Gajanan V., Silverman J. and Raj A. (2016) The Importance of Husbands' Engagement in Family Planning Discussion to Promote Contraception Use for Birth Spacing in Rural India. Asia-Pacific Population Journal. 31 (2) 5-20.

[16] Duru C. B., Nnebue C.C., Iwu A.C., Oluoha R.U., Ndukwu E.U., Nwaigbo E. (2018). Utilization of Family Planning Services among Women of Reproductive Age in Urban and Rural Communities of Imo State, Nigeria: A Comparative Study. Afrimedic Journal, 6(1): 11-26.

[17] Johnson O.E (2017). Determinants of Modern Contraceptive Uptake among Nigerian Women: Evidence from the National Demographic and Health Survey. African Journal of Reproductive Health. 21[3]: 89-95.

[18] Jayalakshmi A*, Kirani, A. **, Prabhakar P K** and Pushpanjali, S.** (2002) A Study of Male Involvement in Family Planning. Health and Population Perspectives and Issues 25 (3): 113 - 123, https://www.researchgate.net/publication/265183365 8:2582-6.
[19] Mutombo N. and Bakibinga P. (2014). The effect of joint contraceptive decisions on the use of Injectables, Long-Acting and Permanent Methods (ILAPMs) among married female (15-49) contraceptive users in Zambia: a cross-sectional study. Reproductive Health. 11:51 http://www.reproductive-healthjournal.com/content/11/1/51.

[20] Blackstone, S. R., \& Iwelunmor, J. (2017). Determinants of contraceptive use among Nigerian couples: evidence from the 2013 Demographic and Health Survey. Contraception and reproductive medicine, 2(1), 1-8.

[21] Omololu Adegbola, Fatimah Murtazha, Habeebu-Adeyemi, (2016). The influence of male partners on contraceptive usage in sub-Saharan Africa-Lagos experience. Vol. 13, Issue 3, Pg. 112116. doI: $10.4103 / 2468-6859.185247$ http://www.jcsjournal.org/article.asp?issn=2468685 9 ; year $=2016$; volume $=13$; issue $=3$; spage $=112$; epage $=$ 116; aulast=Adegbola.

[22] Jain, A., Ismail, H., Tobey, E., \& Erulkar, A. (2019). Stigma as a barrier to family planning use among married Youth in Ethiopia. Journal of biosocial science, 51(4), 505-519. 